\title{
Differentiation of flea communities infesting small mammals across selected habitats of the Baltic coast, central lowlands, and southern mountains of Poland
}

\author{
Krzysztof Kowalski • Urszula Eichert • \\ Michal Bogdziewicz • Leszek Rychlik
}

Received: 28 December 2013 / Accepted: 11 February 2014 / Published online: 12 March 2014

(C) The Author(s) 2014. This article is published with open access at Springerlink.com

\begin{abstract}
Only a few studies comparing flea composition on the coast and in the mountains have been conducted. We investigated differences in flea communities infesting small mammals in selected habitats in northern, central, and southern Poland. We predicted (1) a greater number of flea species in the southeastern Poland and a lower number in the north, (2) a greater number of flea species in fertile and wet habitats than in poor and arid habitats, and (3) a low similarity of flea species between flea communities in western and eastern Poland. We found a negative effect of increasing latitude on flea species richness. We suppose that the mountains providing a variety of environments and the limits of the geographic ranges of several flea subspecies in southeastern Poland result in a higher number of flea species. There was a positive effect of increasing wetness of habitat on flea species richness. We found a high diversity in flea species composition between western and eastern Poland (beta diversity=11) and between central and eastern Poland (beta diversity=12). Recolonization of Poland by small mammals and their ectoparasites from different (western and eastern) refugees can affect on this high diversity of flea species.
\end{abstract}

Keywords Alpha and beta diversity · Biogeography $\cdot$ Fleas . Latitude $\cdot$ Small mammals $\cdot$ Poland

\section{Introduction}

Species composition of fleas is affected by a variety of abiotic (e.g., temperature, humidity, precipitation, and elevation or

K. Kowalski $(\bowtie) \cdot$ U. Eichert $\cdot$ M. Bogdziewicz $\cdot$ L. Rychlik Department of Systematic Zoology, Institute of Environmental Biology, Faculty of Biology, Adam Mickiewicz University, Umultowska 89, Poznań 61-614, Poland

e-mail: kowalski.biol@gmail.com structure of the substrate) and biotic factors (e.g., host species, its age, sex, behavior, and habitat preferences) (Marshall 1981; Krasnov et al. 2007, 2010b; Pawelczyk et al. 2004). Hosts with similar habitat requirements and diet can be infected by similar or even identical flea species (Krasnov et al. 2006b; Klimpel et al. 2007). The composition of flea species on host species is determined not only by host-flea relations but also by host-habitat relations. Therefore, a habitat for fleas is not a particular host or a group of hosts but rather a particular host or a group of hosts inside a particular habitat (Krasnov et al. 2006b). In addition, flea species composition varies less (1) among populations of the same host species than among different host species and (2) among habitats of the same type than among different habitats (Poulin and Valtonen 2002; Krasnov et al. 2006b).

Social species living in large family groups, like many rodents, are characterized by a higher prevalence of parasites than less social species like shrews, which are more solitary (Rychlik 1998; Karbowiak et al. 2005; Oguge et al. 2009; Krasnov et al. 2010a). In a more social animal, contacts between individuals are much more frequent which promotes the exchange of fleas. Similarly, increased densities have the same effect as increasing the number of contacts between individuals in population. So, high densities of fleas should mirror high host densities (Rödl 1979; Laakkonen 2000).

Flea species composition depends on the depth and stability of the host's burrow (Krasnov et al. 2006a). Deep and permanent burrows with a constant microclimate seem to be a better habitat for fleas than the shallow and temporary burrows. As a result, the hosts living in deep and permanent burrows may have higher number of flea species and higher prevalence than hosts living in ephemeral and ground burrows (Krasnov et al. 2004, 2010a).

This study aimed to find differences in the flea species composition of small mammals in selected habitats of the 
Baltic coast, the central lowlands, and mountains of Poland. Due to the biogeography rule, the biodiversity of plant and animal species decreases with increasing latitude (Rohde 1992; Rosenzweig 1992; Krasnov et al. 2004; Pavoine and Bonsall 2011). Additionally, due to the fact that in Poland we can find the limits of the geographic ranges of several flea species and subspecies (Skuratowicz 1967; Bartkowska 1973, 1977), we predicted that (1) a greater number of flea species will be noted in the southeastern Poland and a lower number in the north. Moreover, fauna of small mammals is usually richer in fertile and wet habitats (e.g., Aulak 1970). We thus predicted that (2) a greater number of flea species will be recorded in fertile and wet habitats and a lower number in poor and arid habitats. There are some proofs that after the last glaciation, Poland was re-colonized by small mammals and their ectoparasites from different (western and eastern) refugees (Michaux et al. 2004, 2005; Deffontaine et al. 2005; Nieberding et al. 2008). Therefore, we expected (3) a low similarity of flea species between flea communities in western and eastern Poland.

\section{Materials and methods}

Study area

In total, 19 study plots were located in selected habitats of four regions: the Baltic coast (Słowiński National Park), the western lowlands (Gorzowska Forest), the central lowlands (Konin lakes area), and the mountains in the southeast (Bieszczady Mountains) of Poland (Fig. 1). In the Słowiński National Park (SNP), we established seven study plots. Plots S1-S4 were

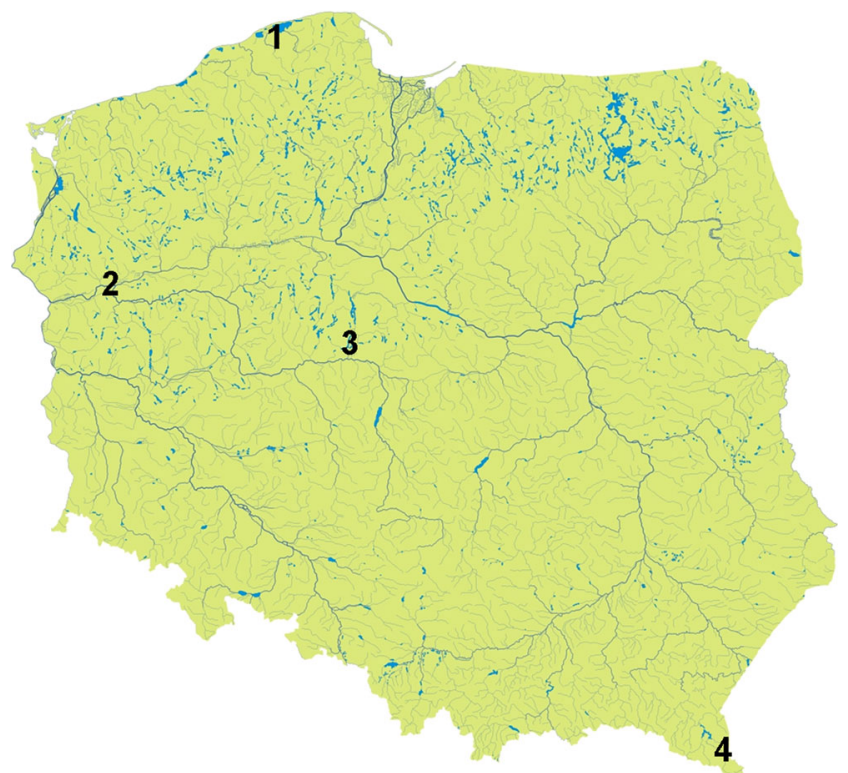

Fig. 1 The location of the study plots: 1 Słowiński National Park, 2 Gorzowska Forest, 3 Konin lakes area, 4 Bieszczady Mountains located in the central part of the park and were investigated for 2 weeks in late July and August 2010 (Table 4 in Appendix). Plots S5-S7 were located on the spit separating the Baltic Sea from the Gardno Lake (the western part of the park) and were studied in September 2011 (1 week). In the Gorzowska Forest, the study was conducted in July 2010 on two plots and in the Konin lakes area on eight plots from August to October 2011. In the Bieszczady Mountains, research was conducted for 5 days in August 2011 on two study plots near Lutowiska village.

\section{Trapping procedure}

Small mammals were captured in wooden live traps, which were usually arranged in three parallel lines with 10 traps in each line (except S4, S7, G1, G2, and K4; see Table 4 in Appendix). The first line was located directly along the shoreline (traps were set within $1 \mathrm{~m}$ from water) or in the wettest habitat. The next two lines were set at distances about 10 and $20 \mathrm{~m}$ from the first line. The traps were spaced at approximately 10-m intervals within lines so it can be assumed that each study plot covered approximately 0.30 ha. Only in Gorzowska Forest traps were arranged in eight lines with eight traps in each line and covered 0.49 ha. We placed food (oat flakes and minced beef) in the traps as bait and as provision for captured animals. Trapping sessions were carried out at night for 5-10 days in the Słowiński National Park and for 3-4 days in the Bieszczady Mountains. Within the Konin lakes area, the study was carried out non-stop for 2 days. Traps were set in the afternoon and checked every $3-4 \mathrm{~h}$ in areas inhabited by shrews or every $5-6 \mathrm{~h}$ in areas inhabited only by rodents. In Gorzowska Forest, traps were active non-stop and checked twice a day for five consecutive days. The captured animals' species were determined and they weighed. We recorded also their age, sex, and reproductive activity and individually marked by ear tagging (Gorzowska Forest) or cutting a small patch of fur (other locations). Then, mammals were placed in a canvas bag for 2-3 min to collect fleas (e.g., Haas and Walton 1973, Paramasvaran et al. 2009, Zuo et al. 2011). The collected fleas were placed in a vial with alcohol, and mammals were released at the place of capture.

\section{Data analysis}

We analyzed the relationship between (1) the latitude and number of flea species and (2) between habitat richness and number of flea species using generalized linear mixed models implemented via "Ime4" package (Bates et al. 2011). In both analyses, we used a number of flea species as response variable and location as random factor. In analysis (1) latitude, abundance of small mammals, number of small mammal species, and abundance of fleas were implemented as fixed factors, whereas in analysis (2) we used habitat wetness and 
habitat fertility, abundance of small mammals, number of small mammal species, and abundance of fleas as fixed factors. In both analyses we used Poisson error distribution, and we began with a model containing all the above mentioned explanatory variables and determined the structure of the final model through backward stepwise elimination of nonsignificant factors using likelihood ratio test. For the purpose of analysis (2), we categorized all habitats into five classes of wetness (1-least wet, 5-most wet) and five classes of fertility (1-least fertile, 5-most fertile). Habitats were assigned to fertility classes based on undergrowth density and the thickness of the litter and to wetness categories based on differences in plant communities. All the analyses were conducted in R software (R Development Core Team 2012).

We measured the alpha and beta diversity to find differences in species composition between flea communities in western and eastern Poland. Alpha diversity refers to the diversity within particular area (or ecosystem) and is usually expressed by the number of species (i.e., species richness) in that area. In turn, beta diversity refers to the total number of species that are unique to each of the areas (or ecosystems) being compared (Whittaker 1972, Harrison et al. 2004).

\section{Results}

\section{Small mammals captured}

In the Słowiński National Park, we captured 60 small mammals belonging to four rodent and three shrew species in 2010 and 34 mammals belonging to five rodent and two shrew species in 2011 (see Table 5 in Appendix). In the Konin lakes area, we captured 187 small mammals belonging to four rodent and two shrew species. In the Gorzowska Forest, we recorded 125 rodents belonging to two species, and in the Bieszczady Mountains, 75 small mammals belonging to five rodents and three shrews.

\section{Fleas collected}

In total, on all study plots, we collected 634 individuals of fleas belonging to 17 species and subspecies. In the Słowiński National Park, we collected 18 individuals belonging to three species of fleas in 2010 and 65 fleas belonging to eight species in 2011 (Table 1). In the Gorzowska Forest, we found 294 fleas belonging to five species, and in the Bieszczady Mountains, we collected 110 fleas belonging to seven species and subspecies. In the Konin lakes area, we recorded 147 fleas belonging to 13 species (Table 2).
Factors influencing diversity of fleas

The final model in analysis (1) revealed in backward procedure included only latitude as an explanatory variable and the effect of increasing latitude on flea species richness was negative $\left(z_{4,18}=-2.50, p=0.01\right.$; Fig. 2$)$. In the case of analysis (2), the final model included habitat wetness and habitat fertility as an explanatory variables. The differences in flea species number between habitats of different wetness categories were significant with increasing number of flea species along with the increasing humidity of habitat (Fig. 3). We found no pattern in relationship between number of flea species and habitat fertility.

The alpha diversity (species richness) for western Poland was 10, 13 for central, and 7 for eastern Poland. We found a low similarity of flea species/subspecies between western and eastern Poland (beta diversity $=11$ ) and between central and eastern Poland (beta diversity=12). The flea species composition of western and central Poland was more similar (beta diversity $=5$; Table 3 ).

\section{Discussion}

In accordance with our predictions, we recorded the inverse relationship between latitude and the number of flea species. In the same time, we found no effect of flea abundance, small mammal abundance, and number of small mammal species on number of flea species recorded. Overall, a well-known rule of biogeography is that the biodiversity of plant and animal species decreases with the increase of the distance from the equator (Rohde 1992; Rosenzweig 1992; Krasnov et al. 2004; Pavoine and Bonsall 2011). On the other hand, Krasnov et al. (2007) reported that the number of flea species in the region increases with the average elevation. This is likely not caused directly by the variation in altitude, but rather the presence of mountains, which presumably provide a variety of environments within the region, possibly resulting in a higher number of flea species. This relationship has been confirmed for Palaeoarctic realm (including Tatry Mountains), where they conducted their research, but have not been confirmed for Nearctic realm. Generally, this relationship is concerned for ectoparasites, which are susceptible to environmental factors that vary with the latitude (Krasnov et al. 2007). In contrast, endoparasites due to their stable habitat (inside the host body) do not show this relationship (Rohde and Heap 1998). Our studies were conducted in the Palearctic realm, and two study plots were located in the mountains. So, the high number of flea species in the Bieszczady Mountains can be explained by the availability of more diverse environments in this region. In addition, in Poland, we can find the northwestern limits of the geographic ranges of several flea species, which may also result in a high number of species in the southeastern part of the country 


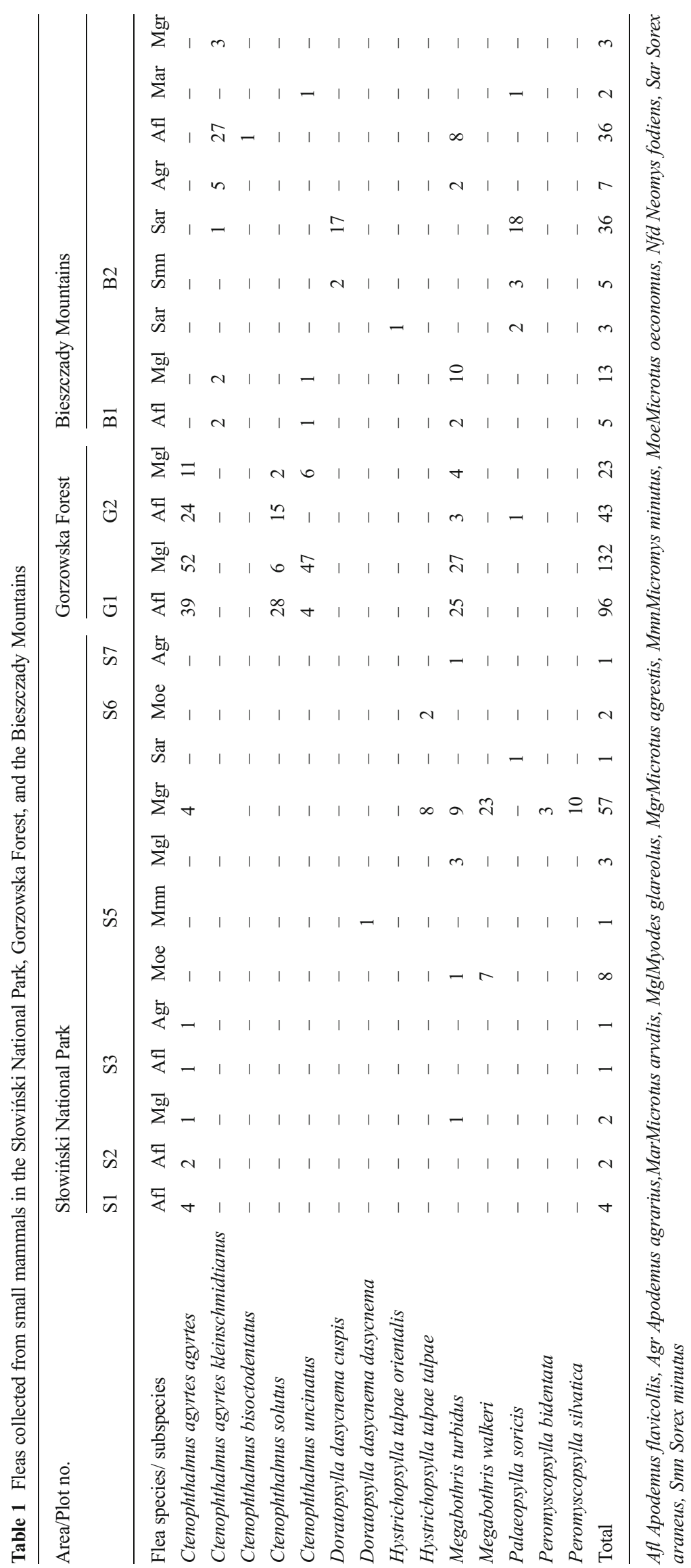


Table 2 Fleas collected from small mammals in the Konin lake area. Mammal species codes as in Table 5

\begin{tabular}{|c|c|c|c|c|c|c|c|c|c|c|c|c|c|c|c|c|c|c|}
\hline \multirow{2}{*}{$\begin{array}{l}\text { Plot no. } \\
\text { Flea species/subspecies }\end{array}$} & \multicolumn{2}{|l|}{$\mathrm{K} 1$} & \multirow{2}{*}{$\begin{array}{l}\mathrm{K} 2 \\
\mathrm{Mg} 1\end{array}$} & \multicolumn{4}{|l|}{$\mathrm{K} 3$} & \multirow{2}{*}{$\begin{array}{l}\text { K4 } \\
\text { Afl }\end{array}$} & \multicolumn{4}{|l|}{$\mathrm{K} 5$} & \multicolumn{3}{|l|}{ K6 } & \multicolumn{2}{|l|}{ K7 } & \multirow{2}{*}{$\begin{array}{l}\text { K8 } \\
\text { Agr }\end{array}$} \\
\hline & Agr & $\mathrm{Mgl}$ & & Agr & Afl & $\mathrm{Mgl}$ & Nfd & & Agr & Afl & Asl & $\mathrm{Mgl}$ & Agr & $\mathrm{Mgl}$ & Sar & Afl & Sar & \\
\hline Ctenophthalmus agyrtes agyrtes & 7 & 2 & - & 1 & 1 & 1 & - & 1 & 3 & 1 & - & 1 & 8 & 4 & - & 1 & - & 1 \\
\hline Ctenophthalmus agyrtes peusianus & - & - & - & - & - & - & - & - & - & - & - & - & - & 1 & - & - & - & - \\
\hline Ctenophthalmus assimilis & - & - & - & - & - & - & - & - & - & - & - & - & - & - & 1 & - & - & - \\
\hline Ctenophthalmus bisoctodentatus & 2 & - & - & - & - & - & - & - & - & - & - & - & - & - & - & - & - & - \\
\hline Ctenophthalmus solutus & - & - & - & - & - & - & - & 4 & 4 & 1 & - & - & - & - & - & - & - & - \\
\hline Ctenophthalmus uncinatus & 1 & 1 & 1 & - & - & 1 & - & - & - & - & - & - & - & - & - & - & - & - \\
\hline Doratopsylla dasycnema dasycnema & - & - & - & - & - & - & - & - & - & - & - & - & - & - & - & - & 1 & 1 \\
\hline Hystrichopsylla talpae talpae & - & - & - & - & - & 1 & - & 1 & 1 & - & - & - & 1 & - & - & - & 2 & - \\
\hline Megabothris turbidus & 20 & 20 & 2 & 1 & 2 & 8 & 1 & 2 & 1 & 2 & - & 3 & 4 & - & - & 1 & - & 1 \\
\hline Megabothris walkeri & - & - & - & - & - & - & - & - & 1 & - & - & - & - & - & - & - & - & - \\
\hline Nosopsyllus fasciatus & - & - & - & - & - & - & - & - & 5 & - & 2 & - & 9 & - & - & - & - & - \\
\hline Palaeopsylla soricis & - & - & - & - & - & 1 & - & - & - & - & - & - & - & - & 2 & - & 1 & - \\
\hline Peromyscopsylla bidentata & - & - & - & - & - & - & - & - & - & - & - & - & - & 1 & - & - & - & - \\
\hline Total & 30 & 23 & 3 & 2 & 3 & 12 & 1 & 8 & 15 & 4 & 2 & 4 & 22 & 6 & 3 & 2 & 4 & 3 \\
\hline
\end{tabular}

(Bartkowska 1977). On the Baltic coast, the most abundant flea was Megabothris walkeri reaching the southern range in Poland. In the Bieszczady Mountains, we found two flea subspecies which reach their western geographic ranges in this region: Hystrichopsylla talpae orientalis and Doratopsylla dasycnema cuspis. Other authors also recorded these fleas in mountain areas (Skuratowicz 1967; Bartkowska 1973, 1977).

Nevertheless, the number of flea species not always is lower at higher latitudes. Krasnov et al. (2004) found a positive correlation between latitude and the number of flea species in the Palearctic realm. They suggest that the reason may be many species of mammals living in regions of temperate climate inhabit deeper and more permanent burrows than those of mammals from warmer regions, which in turn are more preferred by fleas (Krasnov et al. 2004, 2006a, 2010a) because they spend a large part of their life in the host nest. Our research was conducted only in Poland, i.e., only under temperate climate, so generally most small mammals living here can possess deeper burrows than mammals living in tropical regions. However, sandy grounds on the Baltic coast likely hinder digging deep burrows (Haitlinger 1972), which could result in observed lower number of flea species in the north.

There are some proofs that after the last glaciation, Poland was re-colonized by small mammals and their ectoparasites from different (western and eastern) refugees (Michaux et al. 2004, 2005; Deffontaine et al. 2005; Wójcik et al. 2010). Therefore, we expected differences in species composition between flea communities in western and eastern Poland. The results of our study confirmed our predictions. We found a low similarity between western and eastern Poland (11 species and
Fig. 2 Number of flea species in different geographical localizations (with Bieszczady being outermost South and SNP farthest North). Boxes denote 25th, 50th, and 75th percentiles; whiskers represent the lowest and highest datum within the 1.5 interquartile range of the lower and upper quartile

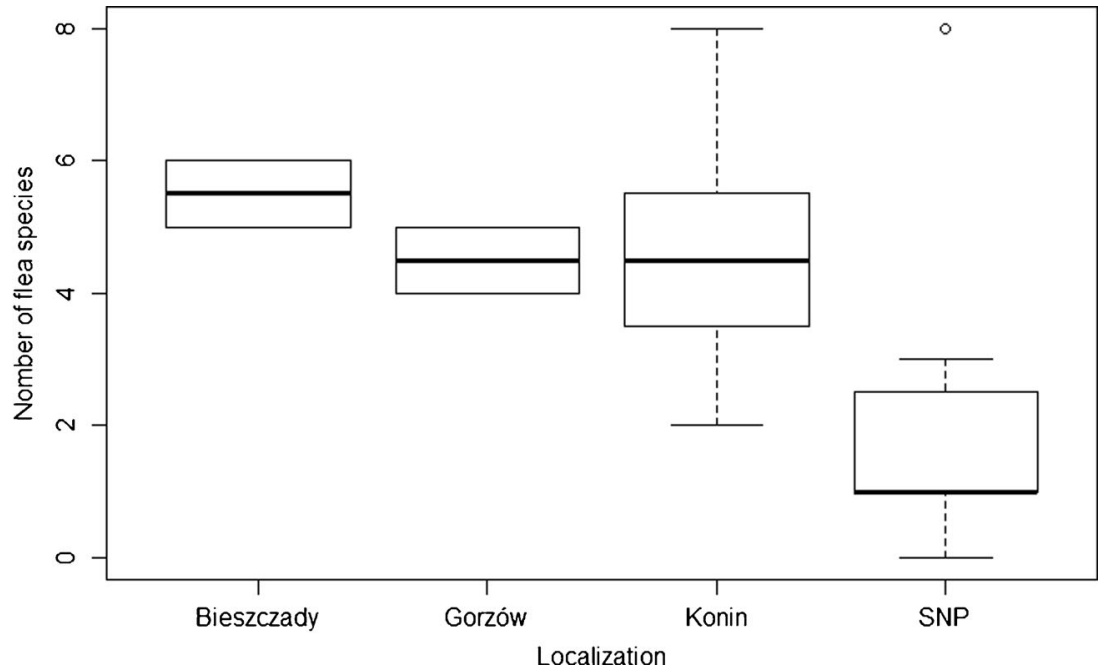


Fig. 3 Number of flea species in habitats of different wetness categories. The differences between category 1 and categories 3 and 4 are significant $(p<0.05)$, and the difference between categories 1 and 2 is approaching significance $(p=$ 0.08). Whiskers indicate standard errors

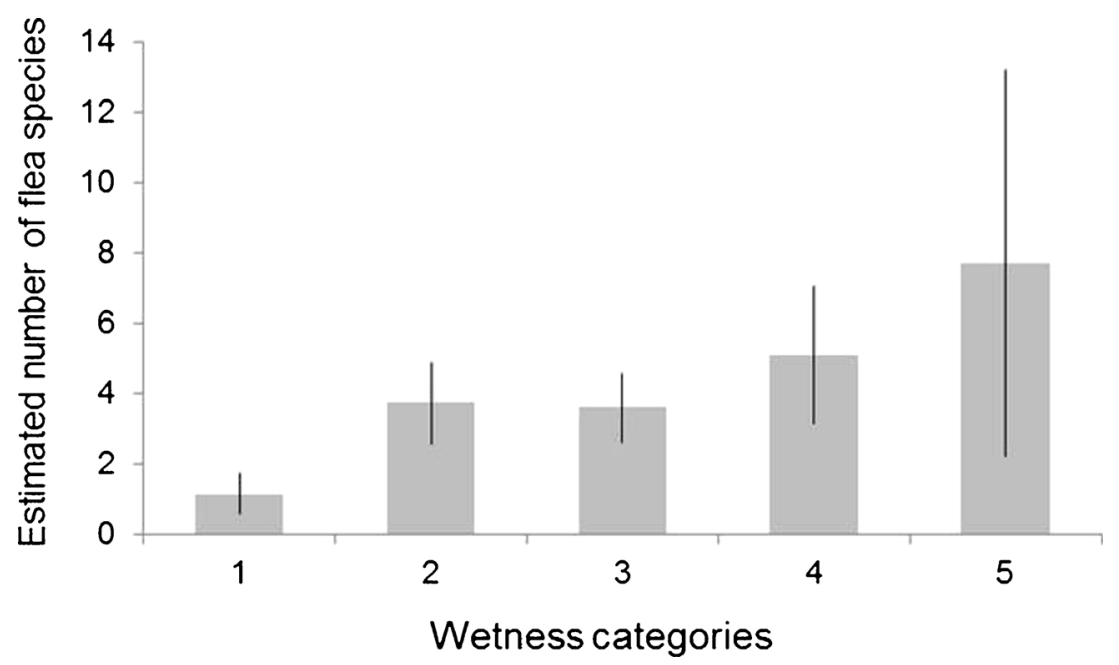

subspecies). In the Bieszczady Mountains, we found four flea species/subspecies (H. talpae orientalis, Ctenophthalmus agyrtes kleinschmidtianus, Ctenophthalmus bisoctodentatus, and Doratopsylla dasycnema cuspis) which were absent in western Poland. Hystrichopsylla talpae orientalis, D. dasycnema cuspis, and C. agyrtes kleinschmidtianus reach their western geographic ranges in this region of Poland. In turn, seven flea species/subspecies were found only in western Poland. We found Peromyscopsylla silvatica only in western Poland, but Bartkowska (1973) found it in Tatry Mountains (southern Poland). In turn, Skuratowicz (1967) indicates that this species occurs in Pomeranian region. Similarly, we reported a low similarity of flea species between central and eastern Poland (12 species/subspecies).

Aulak (1970) indicates that usually fauna of small mammals is richer in fertile and wet habitats. Thus, we supposed that a greater number of flea species could be recorded in fertile and wet habitats and lower in poor and arid habitats. The results of our study confirmed our predictions about the relationship between wetness of habitat and the number of flea species. However, this was not due to the increased number of host species or host abundance on richer habitats as we found no effect of habitat fertility or habitat wetness on number of small mammal species recorded or on small mammal

Table 3 Alpha and beta diversity for flea species/subspecies infesting small mammals in western (Słowiński National Park and Gorzowska Forest), central (Konin lakes area), and eastern (Bieszczady Mountains) Poland

\begin{tabular}{|c|c|c|c|}
\hline Flea species/subspecies & Western Poland & Central Poland & Eastern Poland \\
\hline Ctenophthalmus agyrtes agyrtes & $\mathrm{x}$ & $\mathrm{x}$ & \\
\hline Ctenophthalmus agyrtes kleinschmidtianus & & & $\mathrm{x}$ \\
\hline Ctenophthalmus agyrtes peusianus & & $\mathrm{x}$ & \\
\hline Ctenophthalmus assimilis & & $\mathrm{x}$ & \\
\hline Ctenophthalmus bisoctodentatus & & $\mathrm{x}$ & $\mathrm{x}$ \\
\hline Ctenophthalmus solutus & $\mathrm{x}$ & $\mathrm{x}$ & \\
\hline Ctenophthalmus uncinatus & $\mathrm{x}$ & $\mathrm{x}$ & $\mathrm{x}$ \\
\hline Doratopsylla dasycnema cuspis & & & $\mathrm{x}$ \\
\hline Doratopsylla dasycnema dasycnema & $\mathrm{x}$ & $\mathrm{x}$ & \\
\hline Hystrichopsylla talpae orientalis & & & $\mathrm{x}$ \\
\hline Hystrichopsylla talpae talpae & $\mathrm{x}$ & $\mathrm{x}$ & \\
\hline Megabothris turbidus & $\mathrm{x}$ & $\mathrm{x}$ & $\mathrm{x}$ \\
\hline Megabothris walkeri & $\mathrm{x}$ & $\mathrm{x}$ & \\
\hline Nosopsyllus fasciatus & & $\mathrm{x}$ & \\
\hline Palaeopsylla soricis & $\mathrm{x}$ & $\mathrm{x}$ & $\mathrm{x}$ \\
\hline Peromyscopsylla bidentata & $\mathrm{x}$ & $\mathrm{x}$ & \\
\hline Peromyscopsylla silvatica & $\mathrm{x}$ & & \\
\hline Alpha diversity & 10 & 13 & 7 \\
\hline Beta diversity & Western vs. central Poland: 5 & Central vs. eastern Poland: 12 & Western vs. eastern Poland: 11 \\
\hline
\end{tabular}


abundance. The increased number of flea species recorded in more wet habitats could be due to the fact that humidity has a strong influence on the development of flea larvae (Skuratowicz 1967, Krasnov et al. 2006a) and relative humidity within burrows is one of the main factors influencing flea development and survival (Krasnov et al. 2001, OsacarJimenez et al. 2001). Therefore, more humid habitats could be suitable for bigger number of flea species than arid ones. On the other hand, we found no relationship between richness of habitat and the number of flea species.

Short term of our study undoubtedly had a negative impact on the number of captured mammals and collected fleas. It is probable that, with larger sample sizes and sampling in more localities, some of our predictions and observed trends would obtain stronger support. So, further studies are required to accurately determine the differentiation in flea species composition of small mammals in selected regions of Poland. Due to the fact that in Poland fleas spend the most of their time in host nests (Skuratowicz 1967; Krasnov et al. 2010a), fleas should be collected from both small mammals captured in live traps as well as from host nests. Additionally, it would be desirable to investigate more study plots in Pomerania region and highlands in order to increase the range of data allowing for determination of the impact of both latitude and longitude on flea communities.

Acknowledgments We are very grateful to A. Stachowiak, P. Kardynia, N. Osten-Sacken, D. Matuszyk, and W. Eichert for help in field works; to K. Woźniak (director of SNP), I. Izydorek, and D. Staniaszek (from SNP) for allowing us to conduct our studies in the Park; to S. Pagacz and J. Witczuk for allowing us to conduct studies near Lutowiska village; and to R. Zwolak and S. Dziemian for access to research material collected in Gorzowska Forest. Our special thanks go to A. Brzeg and M. Wojterska for the botanical consultations, to B. Piłacińska for the help in determining some rodents, to R. Bajaczyk for the help in determining some flea species, and to S. von Merten and R. Zwolak for the advice and their comments on the manuscript. The research was supported by grant no. SFRH/BD/ 31602/2006 from the Science and Technology Foundation (Portuguese Ministry of Science, Technology and Higher Education) and the budget of the Department of Systematic Zoology (Faculty of Biology AMU, Poznań).

Ethical standards All handling of animals was done with permissions received from the Local Ethical Committee for the Animal Experiments in Poznań, the General Director for Environmental Protection, and from the Polish Minister of the Environment.

Conflict of interest The authors declare that they have no conflict of interest.

\section{Appendix}

Table 4 Description of the 19 study plots in the Słowiński National Park, Gorzowska Forest, Konin lakes area and in the Bieszczady Mountains, including Habitat richness and humidity, and trapping effort

\begin{tabular}{|c|c|c|c|c|c|c|c|}
\hline Plot no. & $\begin{array}{l}\text { Latitude and } \\
\text { longitude }\end{array}$ & Plot description & Wetness & Richness & $\begin{array}{l}\text { Trapping } \\
\text { season }\end{array}$ & $\begin{array}{l}\text { Number and layout } \\
\text { of traps }\end{array}$ & $\begin{array}{l}\text { Trapping effort } \\
\text { [trap-hours] }\end{array}$ \\
\hline \multicolumn{8}{|c|}{ Słowiński National Park } \\
\hline S1 & $\begin{array}{l}54^{\circ} 41^{\prime} 59.74^{\prime \prime} \mathrm{N}, 17^{\circ} \\
\quad 18^{\prime} 31.39^{\prime \prime} \mathrm{E}\end{array}$ & $\begin{array}{l}\text { Community similar to Pomeranian fertile } \\
\text { beech forest Melico-Fagetum on moist } \\
\text { soil; dominant plants: Molinia cerulea, } \\
\text { Fagus silvatica, Quercus sessilis }\end{array}$ & 2 & 1 & July 2010 & $\begin{array}{l}\text { Grid: } 3 \text { parallel lines } \\
\text { of } 10 \text { box traps }\end{array}$ & 4,350 \\
\hline S2 & $\begin{array}{l}54^{\circ} 41^{\prime} 52.96^{\prime \prime} \mathrm{N}, 17^{\circ} \\
\quad 18^{\prime} 47.83^{\prime \prime} \mathrm{E}\end{array}$ & $\begin{array}{l}\text { Peat alder forest Sphagno squarrosi- } \\
\text { Alnetum, wet (water from } 20 \mathrm{~cm} \text { below } \\
\text { ground surface to } 20 \mathrm{~cm} \text { deep); } \\
\text { dominant plants: Pteridium aquilinum, } \\
\text { Molinia cerulea, Alnus glutinosa, Betula } \\
\text { pubescens }\end{array}$ & 3 & 5 & July 2010 & $\begin{array}{l}\text { Grid: } 3 \text { parallel lines } \\
\text { of } 10 \text { box traps }\end{array}$ & 2,700 \\
\hline S3 & $\begin{array}{l}54^{\circ} 41^{\prime} 40.00^{\prime \prime} \mathrm{N}, 17^{\circ} \\
\quad 12^{\prime} 25.50^{\prime \prime} \mathrm{E}\end{array}$ & $\begin{array}{l}\text { Reeds Phalaridetum arundinaceae, wet } \\
\text { (water 0-30 cm deep); dominant plants: } \\
\text { Phalaris arundinacea, Carex } \\
\text { pseudocyperus, Glyceria maxima }\end{array}$ & 5 & 4 & Aug 2010 & $\begin{array}{l}\text { Grid: } 3 \text { parallel lines } \\
\text { of } 10 \text { box traps }\end{array}$ & 1,185 \\
\hline S4 & $\begin{array}{l}54^{\circ} 42^{\prime} 4.95^{\prime \prime} \mathrm{N}, 17^{\circ} \\
12^{\prime} 38.43^{\prime \prime} \mathrm{E}\end{array}$ & $\begin{array}{l}\text { Alder forest (shore of Dołgie Lake) and a } \\
\text { mosaic of plant communities Iridetum } \\
\text { pseudacori and Cicuto-Caricetum } \\
\text { pseudocyperi (water } 20-30 \mathrm{~cm} \text { deep); } \\
\text { dominant plants: Carex pseudocyperus, } \\
\text { Iris pseudoacorus, Carex nigra, Alnus } \\
\text { glutinosa, Betula pubescens }\end{array}$ & 5 & 4 & Aug 2010 & $\begin{array}{l}\text { Grid: } 2 \text { parallel lines } \\
\text { of } 15 \text { box traps }\end{array}$ & 1,125 \\
\hline S5 & $\begin{array}{c}54^{\circ} 40^{\prime} 17.39^{\prime \prime} \mathrm{N}, 17^{\circ} \\
05^{\prime} 19.60^{\prime \prime} \mathrm{E}\end{array}$ & Seaside pine forest Empetro nigri-Pinetum & 3 & 4 & Sep 2011 & $\begin{array}{l}\text { Grid: } 3 \text { parallel lines } \\
\text { of } 10 \text { box traps }\end{array}$ & 3,600 \\
\hline
\end{tabular}


Table 4 (continued)

\begin{tabular}{|c|c|c|c|c|c|c|c|}
\hline Plot no. & $\begin{array}{l}\text { Latitude and } \\
\text { longitude }\end{array}$ & Plot description & Wetness & Richness & $\begin{array}{l}\text { Trapping } \\
\text { season }\end{array}$ & $\begin{array}{l}\text { Number and layout } \\
\text { of traps }\end{array}$ & $\begin{array}{l}\text { Trapping effort } \\
\text { [trap-hours] }\end{array}$ \\
\hline S6 & $\begin{array}{l}54^{\circ} 40^{\prime} 29.63^{\prime \prime} \mathrm{N}, 17^{\circ} \\
03^{\prime} 55.27^{\prime \prime} \mathrm{E}\end{array}$ & Wet meadow & 4 & 2 & Sep 2011 & $\begin{array}{l}\text { Grid: } 3 \text { parallel lines } \\
\text { of } 10(14) \text { box } \\
\text { traps }\end{array}$ & 3,600 \\
\hline S7 & $\begin{array}{l}54^{\circ} 40^{\prime} 23.92^{\prime \prime} \mathrm{N}, 17^{\circ} \\
04^{\prime} 00.11^{\prime \prime} \mathrm{E}\end{array}$ & $\begin{array}{l}\text { White dune Elymo- } \\
\text { Ammophiletun arenariae }\end{array}$ & 1 & 1 & Sep 2011 & $\begin{array}{l}\text { Grid: } 2 \text { parallel lines } \\
\text { of } 15 \text { box traps }\end{array}$ & 3,600 \\
\hline \multicolumn{8}{|c|}{ Gorzowska Forest } \\
\hline G1 & $\begin{array}{l}52^{\circ} 41^{\prime} 22.18^{\prime \prime} \mathrm{N}, 15^{\circ} \\
03^{\prime} 43.92^{\prime \prime} \mathrm{E}\end{array}$ & $\begin{array}{l}\text { Wet meadow with individual trees and } \\
\text { shrubs and lush herbaceous vegetation } \\
\text { (herbs and grass) }\end{array}$ & 3 & 4 & July 2010 & $\begin{array}{l}\text { Grid: } 8 \text { parallel lines } \\
\text { of } 8 \text { box traps }\end{array}$ & 36,864 \\
\hline G2 & $\begin{array}{l}52^{\circ} 41^{\prime} 58.14^{\prime \prime} \mathrm{N}, 15^{\circ} \\
04^{\prime} 9.87^{\prime \prime} \mathrm{E}\end{array}$ & Beech forest & 2 & 2 & July 2010 & $\begin{array}{l}\text { Grid: } 8 \text { parallel lines } \\
\text { of } 8 \text { box traps }\end{array}$ & 36,864 \\
\hline \multicolumn{8}{|c|}{ Konin lakes area } \\
\hline K1 & $\begin{array}{l}52^{\circ} 18^{\prime} 9.17^{\prime \prime} \mathrm{N}, 18^{\circ} \\
19^{\prime} 11.50^{\prime \prime} \mathrm{E}\end{array}$ & $\begin{array}{l}\text { Three microhabitats: lake bank with lush } \\
\text { vegetation, herbs and bulrush; channel } \\
\text { leading eutrophic water to a nearby } \\
\text { wetland and ecotone between rather dry } \\
\text { and wet meadow (southwestern bank of } \\
\text { Licheńskie Lake) }\end{array}$ & 3 & 5 & Aug 2011 & $\begin{array}{l}\text { Grid: } 3 \text { parallel lines } \\
\text { of } 10 \text { box traps }\end{array}$ & 1,290 \\
\hline $\mathrm{K} 2$ & $\begin{array}{l}52^{\circ} 18^{\prime} 25.80^{\prime \prime} \mathrm{N}, 18^{\circ} \\
\quad 18^{\prime} 21.98^{\prime \prime} \mathrm{E}\end{array}$ & $\begin{array}{l}\text { Dry aspect of alder forest separated with a } \\
\text { causeway from the eastern bank of } \\
\text { Pątnowskie Lake }\end{array}$ & 1 & 1 & Aug 2011 & $\begin{array}{l}\text { Grid: } 3 \text { parallel lines } \\
\text { of } 10 \text { box traps }\end{array}$ & 1,200 \\
\hline $\mathrm{K} 3$ & $\begin{array}{l}52^{\circ} 17^{\prime} 54.63^{\prime \prime} \mathrm{N}, 18^{\circ} \\
11^{\prime} 42.22^{\prime \prime} \mathrm{E}\end{array}$ & $\begin{array}{l}\text { Two microhabitats: bank of a small forest } \\
\text { lake with sedges and herbs, and moist } \\
\text { alder forest (without standing water } \\
\text { between the clumps) with dense stand } \\
\text { ( } 700 \mathrm{~m} \text { west of Gosławskie Lake) }\end{array}$ & 4 & 5 & Aug 2011 & $\begin{array}{l}\text { Grid: } 3 \text { parallel lines } \\
\text { of } 10 \text { box traps }\end{array}$ & 600 \\
\hline K4 & $\begin{array}{l}52^{\circ} 17^{\prime} 43.48^{\prime \prime} \mathrm{N}, 18^{\circ} \\
11^{\prime} 5.14^{\prime \prime} \mathrm{E}\end{array}$ & $\begin{array}{l}\text { Three microhabitats: forest lake bank } \\
\text { overgrowing with the willow bushes and } \\
\text { bulrush; wet (but without standing water } \\
\text { between the clumps) alder forest and } \\
\text { mixed forest on the side of the hill } \\
\text { ( } 500 \mathrm{~m} \text { north of Skape Lake) }\end{array}$ & 3 & 4 & Aug 2011 & $\begin{array}{l}\text { Grid: } 2 \text { parallel lines } \\
\text { of } 10 \text { box traps } \\
\text { and a separate line } \\
\text { (C) of } 10 \text { box } \\
\text { traps }\end{array}$ & 600 \\
\hline K5 & $\begin{array}{l}52^{\circ} 15^{\prime} 54.40^{\prime \prime} \mathrm{N}, 18^{\circ} \\
15^{\prime} 25.93^{\prime \prime} \mathrm{E}\end{array}$ & $\begin{array}{l}\text { The bank of artificial and polluted lake } \\
\text { including three microhabitats: steep bank } \\
\text { overgrown with reeds, quite moist open } \\
\text { plateau with blackberry and broom } \\
\text { bushes and a steep slope overgrown with } \\
\text { herbs and with a loose trees and grasses }\end{array}$ & 3 & 3 & $\begin{array}{c}\text { October } \\
2011\end{array}$ & $\begin{array}{l}\text { Grid: } 3 \text { parallel lines } \\
\text { of } 10 \text { box traps }\end{array}$ & 1,080 \\
\hline K6 & $\begin{array}{l}52^{\circ} 16^{\prime} 40.35^{\prime} \mathrm{N}, 18^{\circ} \\
\quad 16^{\prime} 14.44^{\prime \prime} \mathrm{E}\end{array}$ & $\begin{array}{l}\text { An anthropogenic and polluted } \\
\text { environment (backwaters near the } \\
\text { "Gosławice" Power); included three } \\
\text { microhabitats: reeds growing on } \\
\text { wetlands bank, sewer bank with lush } \\
\text { rush and slope descending to this sewer } \\
\text { covered with herbaceous vegetation with } \\
\text { a few birches }\end{array}$ & 4 & 3 & $\begin{array}{c}\text { October } \\
2011\end{array}$ & $\begin{array}{l}\text { Grid: } 3 \text { parallel lines } \\
\text { of } 10 \text { box traps }\end{array}$ & 1,080 \\
\hline K7 & $\begin{array}{l}52^{\circ} 19^{\prime} 25.30^{\prime \prime} \mathrm{N}, 18^{\circ} \\
21^{\prime} 7.98^{\prime \prime} \mathrm{E}\end{array}$ & $\begin{array}{l}\text { Three microhabitats: a large glacial lake } \\
\text { bank with a narrow strip of riparian } \\
\text { vegetation, steep slope covered with } \\
\text { mature trees and the plateau with lush } \\
\text { grassy places, old pines and younger } \\
\text { oaks and maples (eastern bank of } \\
\text { Licheńskie Lake) }\end{array}$ & 2 & 2 & $\begin{array}{c}\text { October } \\
2011\end{array}$ & $\begin{array}{l}\text { Grid: } 3 \text { parallel lines } \\
\text { of } 10 \text { box traps }\end{array}$ & 1,860 \\
\hline K8 & $\begin{array}{l}52^{\circ} 20^{\prime} 12.32^{\prime \prime} \mathrm{N}, 18^{\circ} \\
21^{\prime} 28.07^{\prime \prime} \mathrm{E}\end{array}$ & $\begin{array}{l}\text { Two microhabitats: large glacial lake bank } \\
\text { with a narrow strip of riparian vegetation }\end{array}$ & 2 & 2 & $\begin{array}{c}\text { October } \\
2011\end{array}$ & $\begin{array}{l}\text { Grid: } 3 \text { parallel lines } \\
\text { of } 10 \text { box traps }\end{array}$ & 1,860 \\
\hline
\end{tabular}
with reeds and pine forest with herbaceous vegetation (northeastern bank of Licheńskie Lake) 
Table 4 (continued)

\begin{tabular}{|c|c|c|c|c|c|c|c|}
\hline Plot no. & $\begin{array}{l}\text { Latitude and } \\
\text { longitude }\end{array}$ & Plot description & Wetness & Richness & $\begin{array}{l}\text { Trapping } \\
\text { season }\end{array}$ & $\begin{array}{l}\text { Number and layout } \\
\text { of traps }\end{array}$ & $\begin{array}{l}\text { Trapping effort } \\
\text { [trap-hours] }\end{array}$ \\
\hline \multicolumn{8}{|c|}{ Bieszczady Mountains (in/near Lutowiska village) } \\
\hline B1 & $\begin{array}{l}49^{\circ} 14^{\prime} 51.70^{\prime \prime} \mathrm{N}, 22^{\circ} \\
40^{\prime} 14.84^{\prime \prime} \mathrm{E}\end{array}$ & $\begin{array}{l}\text { Pine forest with dense undergrowth } \\
\text { dominated by blackberry }\end{array}$ & 2 & 4 & Aug 2011 & $\begin{array}{l}\text { Grid: } 3 \text { parallel lines } \\
\text { of } 10 \text { box traps }\end{array}$ & 2,070 \\
\hline B2 & $\begin{array}{l}49^{\circ} 15^{\prime} 0.77^{\prime \prime} \mathrm{N}, 22^{\circ} \\
41^{\prime} 24.67^{\prime \prime} \mathrm{E}\end{array}$ & $\begin{array}{l}\text { Banks of a stream running through wet } \\
\text { meadow with individual shrubs and lush } \\
\text { herbaceous vegetation (reeds and herbs) }\end{array}$ & 4 & 3 & Aug 2011 & $\begin{array}{l}\text { Grid: } 3 \text { parallel lines } \\
\text { of } 10 \text { box traps }\end{array}$ & 1,680 \\
\hline
\end{tabular}

Table 5 Species and numbers of all small mammals captured in selected habitats of the Baltic coast, the central lowlands, and mountains of Poland

\begin{tabular}{|c|c|c|c|c|c|c|c|c|c|c|c|c|c|c|c|c|c|c|c|c|}
\hline \multirow[b]{2}{*}{ Mammal species } & \multirow[b]{2}{*}{ Code } & \multicolumn{7}{|c|}{ Słowiński National Park } & \multicolumn{2}{|c|}{ Gorzowska Forest } & \multicolumn{8}{|c|}{ Konin lakes area } & \multicolumn{2}{|c|}{ Bieszczady Mountains } \\
\hline & & S1 & $\mathrm{S} 2$ & $\mathrm{~S} 3$ & $\mathrm{~S} 4$ & S5 & S6 & S7 & G1 & G2 & $\mathrm{K} 1$ & $\mathrm{~K} 2$ & K3 & K4 & K5 & K6 & K7 & K8 & B1 & B2 \\
\hline Apodemus agrarius & Agr & - & - & 1 & 1 & - & 1 & 3 & - & - & 19 & - & 2 & 2 & 14 & 28 & 5 & 4 & - & 5 \\
\hline Apodemus flavicollis & Afl & 4 & 16 & 2 & 1 & - & - & 1 & 49 & 31 & - & 1 & 4 & 9 & 14 & 1 & 3 & 1 & 10 & 23 \\
\hline Apodemus sylvaticus & Asl & - & - & - & - & - & - & - & - & - & - & - & - & - & 4 & - & - & - & - & - \\
\hline Micromys minutus & $\mathrm{Mmn}$ & - & - & - & - & 1 & 12 & - & - & - & - & - & - & - & - & - & - & - & - & - \\
\hline Microtus agrestis & Mgr & - & - & - & - & 9 & - & - & - & - & - & - & - & - & - & - & - & - & - & 1 \\
\hline Microtus arvalis & Mar & - & - & - & - & - & - & - & - & - & - & - & - & - & - & - & - & - & - & 5 \\
\hline Microtus oeconomus & Moe & - & 1 & 10 & 11 & - & 4 & - & - & - & - & - & - & - & - & - & - & - & - & - \\
\hline Myodes glareolus & $\mathrm{Mgl}$ & - & 3 & - & - & 1 & - & - & 44 & 11 & 12 & 3 & 23 & 4 & 11 & 4 & - & - & 14 & - \\
\hline Neomys fodiens & $\mathrm{Nfd}$ & - & - & - & 1 & - & - & - & - & - & 2 & - & 1 & 1 & - & 2 & - & - & - & 2 \\
\hline Sorex araneus & Sar & - & 1 & 1 & 1 & 1 & - & - & - & - & 2 & 1 & 1 & 1 & 1 & 6 & 1 & - & 3 & 11 \\
\hline Sorex minutus & Smn & - & 1 & 2 & 3 & - & 1 & - & - & - & - & - & - & - & - & - & - & - & - & 1 \\
\hline Total & & 4 & 22 & 16 & 18 & 12 & 18 & 4 & 93 & 42 & 35 & 5 & 31 & 17 & 44 & 41 & 9 & 5 & 27 & 48 \\
\hline
\end{tabular}

Open AccessThis article is distributed under the terms of the Creative Commons Attribution License which permits any use, distribution, and reproduction in any medium, provided the original author(s) and the source are credited.

\section{References}

Aulak W (1970) Small mammal communities of the Białowieża National Park. Acta Theriol 15:465-515

Bartkowska K (1973) Siphonaptera Tatr Polskich. Fragm Faun 19:227_283

Bartkowska K (1977) Z badań nad Siphonaptera w Beskidach Zachodnich. Wiad Parazytol 23:219-220

Bates D, Maechler M, Bolker B (2011) lme4: linear mixed-effects models using S4 classes. R package version 0.999375-38. http://CRAN.Rproject.org/package $=1 \mathrm{me} 4$. Accessed 25 Oct 2013

Deffontaine V, Libois R, Kotlik P, Sommer R, Nieberding C, Paradis E, Searle JB, Michaux JR (2005) Beyond the Mediterranean peninsulas: evidence of central European glacial refugia for a temperate forest species, the bank vole (Clethrionomys glareolus). Mol Ecol 14:1727-1739. doi:10.1111/j.1365-294X.2005.02506.x

Haas GE, Walton DW (1973) Fleas (Siphonaptera) infesting small mammals from the Western Oriental Region. Korean J Parasitol 11:102107

Haitlinger R (1972) Drobne ssaki bezleśnych wydm nadmorskich i ich fauna pcheł. Prz Zool 16:231-237

Harrison I, Laverty M, Sterling E (2004) Alpha, beta, and gamma diversity. http://cnx.org/content/m12147/1.2/. Accessed 29 Jul 2004

Karbowiak G, Rychlik L, Nowakowski W, Wita I (2005) Natural infections of small mammals with blood parasites on the borderland of boreal and temperate forest zones. Acta Theriol 50:31-42

Klimpel S, Förster M, Schmall G (2007) Parasites of two abundant sympatric rodent species in relation to host phylogeny and ecology. Parasitol Res 100:867-875. doi:10.1007/s00436-006-0368-8

Krasnov BR, Khokhlova IS, Fielden LJ, Burdelova NV (2001) Development rates of two Xenopsylla flea species in relation to air temperature and humidity. Med Vet Entomol 15:249258

Krasnov BR, Shenbrot GI, Khokhlova IS, Degen AA (2004) Flea species richness and parameters of host body, host geography and host 'milieu'. J Anim Ecol 73:1121-1128 
Krasnov BR, Shenbrot GI, Khokhlova IS, Poulin R (2006a) Is abundance a species attribute? An example with haematophagous ectoparasites. Oecologia 150:132-140. doi:10.1007/s00442-006-0498-9

Krasnov BR, Stanko M, Miklisova D, Morand S (2006b) Habitat variation in species composition of flea assemblages on small mammals in central Europe. Ecol Res 21:460-469. doi:10.1007/s11284-0050142-x

Krasnov BR, Shenbrot GI, Khokhlova IS, Poulin R (2007) Geographical variation in the 'bottom-up' control of diversity: fleas and their small mammalian hosts. Glob Ecol Biogeogr 16:179-186. doi:10.1111/j. 1466-8238.2006.00273.x

Krasnov BR, Matthee S, Lareschi M, Korallo-Vinarskaya NP, Vinarski MV (2010a) Co-occurrence of ectoparasites on rodent hosts: null model analyses of data from three continents. Oikos 119:120-128. doi:10.1111/j.1600-0706.2009.17902.x

Krasnov BR, Mouillot D, Shenbrot GI, Khokhlova IS, Vinarski MV, Korallo-Vinarskaya NP, Poulin R (2010b) Similarity in ectoparasite faunas of Palaearctic rodents as a function of host phylogenetic, geographic or environmental distances: which matters the most? Int J Parasitol 40:807-817. doi:10.1016/j.ijpara.2009.12.002

Laakkonen J (2000) Microparasites of three species of shrews from Finnish Lapland. Ann Zool Fenn 37:37-41

Marshall AG (1981) The ecology of ectoparasitic insects. Academic, London

Michaux JR, Libois R, Paradis E, Filippucci MG (2004) Phylogeographic history of the yellow-necked fieldmouse (Apodemus flavicollis) in Europe and in the Near and Middle East. Mol Phylogenet Evol 32: 788-798. doi:10.1016/j.ympev.2004.02.018

Michaux JR, Libois R, Filippucci MG (2005) So close and so different: comparative phylogeograpgy of two small mammal species, the Yellow-necked fieldmouse (Apodemus flavicollis) and the Woodmouse (Apodemus sylvaticus) in the Western Palearctic region. Hered 94:52-63. doi:10.1038/sj.hdy.6800561

Nieberding CM, Durette-Desset MC, Vanderpoorten A, Casanova JC, Ribas A, Deffontaine V, Feliu C, Morand S, Libois R, Michaux JR (2008) Geography and host biogeography matter for understanding the phylogeography of a parasite. Mol Phylogenet Evol 47:538554. doi:10.1016/j.ympev.2008.01.028

Oguge NO, Durden LA, Keirans JE, Balami HD, Schwan TG (2009) Ectoparasites (sucking lice, fleas, ticks) of small mammals in southeastern Kenya. Med Vet Entomol 23:387-392

Osacar-Jimenez JJ, Lucientes-Curdi J, Calvete-Margolles C (2001) Abiotic factors influencing the ecology of wild rabbit fleas in north-western Spain. Med Vet Entomol 15:157-166
Paramasvaran S, Sani RA, Hassan L, Krishnasamy M, Jeffery J, Oothuman P, Salleh I, Lim KH, Sumarni MG, Santhana RL (2009) Ectoparasite fauna of rodents and shrews from habitats in Kuala Lumpur and the states of Selangor and Negeri Sembilan, Malaysia and its public health significance. Trop Biomed 26:303311

Pawelczyk A, Bajer A, Behnke JM, Gilbert FS, Siński E (2004) Factors affecting the component community structure of haemoparasites in common voles (Microtus arvalis) from the Mazury Lake District region of Poland. Parasitol Res 92:270-284. doi:10.1007/s00436003-1040-1

Pavoine S, Bonsall MB (2011) Measuring biodiversity to explain community assembly: a unified approach. Biol Rev 86:792-812. doi:10. 1111/j.1468-185X.2010.00171.x

Poulin R, Valtonen T (2002) The predictability of helminth community structure in space: a comparison of fish populations from adjacent lakes. Int J Parasitol 32:1235-1243

Rödl P (1979) Investigation of the transfer of fleas among small mammals using radioactive phosphorus. Folia Parasitol 26:265-274

Rohde K (1992) Latitudinal gradients in species diversity: the search for the primary cause. Oikos 65:514-527

Rohde K, Heap M (1998) Latitudinal differences in species and community richness and in community structure of metazoan endo- and ectoparasites of marine teleost fish. Int J Parasitol 28:461-474

Rosenzweig ML (1992) Species diversity gradients: we know more and less than we thought. J Mammal 73:715-730

Rychlik L (1998) Evolution of social systems in shrews. In: Wójcik JM, Wolsan M (eds) Evolution of shrews. Mammal Research Institute, Polish Academy of Sciences, Białowieża, pp 347-406

Skuratowicz W (1967) Klucze do oznaczania owadów Polski. Część XXIX. Pchly - Siphonaptera (Aphaniptera). Polskie Towarzystwo Entomologiczne, Państwowe Wydawnictwo Naukowe, Warszawa

Whittaker RH (1972) Evolution and measurement of species diversity. Taxon 21:213-251

Wójcik JM, Kawałko A, Markova S, Searle JB, Kotlik P (2010) Phylogeographic signatures of northward post-glacial colonization from high-latitude refugia: a case study of bank voles using museum specimens. J Zool 281:249-262. doi:10.1111/j.1469-7998.2010. 00699.x

Zuo XH, Guo XG, Zhan YZ, Wu D, Yang ZH, Dong WG, Huang LQ, Ren TG, Jing YG, Wang QH, Sun XM, Lin SJ (2011) Host selection and niche differentiation in sucking lice (Incecta: Anoplura) among small mammals in southwestern China. Parasitol Res 108:12431251. doi:10.1007/s00436-010-2173-7 